\title{
DETERMINATION OF FACTORS INFLUENCING PRE-SERVICE TEACHERS' SENSE OF SELF-EFFICACY
}

\author{
D. P. Ngidi* \\ Deputy Vice-Chancellor: Teaching and Learning \\ e-mail: dngidi@cut.ac.za
}

\section{S. A. Ngidi*}

Department of Communication Sciences

e-mail: sngidi@cut.ac.za

${ }^{*}$ Central University of Technology, Free State

Bloemfontein, South Africa

\section{ABSTRACT}

This study examined the factors that influence the sense of self efficacy of pre-service teachers at a university of technology in South Africa. To this end, a questionnaire was used in a survey to collect data from the population of fourth-year Bachelor of Education students. The Teachers' Sense of Efficacy Scale (TSES) was used to measure the teaching self-efficacy of pre-service teachers whilst the Eysenck Personality Questionnaire (EPQ) was used to measure their personality dimensions. The findings revealed that pre-service teachers differed in terms of the extent of their teaching self-efficacy. The findings also revealed that gender and study programme had no influence on pre-service teachers' teaching self-efficacy. The findings further revealed that there is no relationship between pre-service teachers' teaching self-efficacy and personality factors, namely neuroticism $(N)$ and extraversion $(E)$. Furthermore, the findings revealed that the programme of study emerged as a significant predictor of efficacy in the classroom management subscale of teaching self-efficacy.

Keywords: pre-service teachers, teaching efficacy beliefs, university of technology, personality dimensions.

\section{INTRODUCTION}

Researchers have displayed a growing interest in the teaching efficacy of pre-service teachers. Consequently, the evolution of self-efficacy beliefs amongst pre-service teachers has developed a plethora of research interest (Dembo and Gibson 1985; Gurol, Ozercan and Yalcin 2010; Knobloch 2006; Matoti, Junqueira and Odora 2011; 2013; Janqueira and Matoti 2013; Roberts, Harlin and Bries 2009; Swan, Wolf and Cano 2011; Spector 2004; Woolfolk Hoy 2000; Woolfolk Hoy and Burke-Spero 2005; Woolfolk and Hoy 1990). The reason for such research interest may be that "once efficacy beliefs are established, they tend to be resistant to change" 
(Bandura 1997; Hoy and Spero 2005).

Several studies have established that teachers with high levels of self-efficacy seem to be keen to experiment new methods and strategies to accommodate students' needs (Cousins and Walker 2000); "show greater commitment to teaching" (Coladarci 1992); never surrender effortlessly despite adversities and disappointments; spend more time with a less coping student, and become less condemning of students' mistakes (Ashton and Webb 1986; Gibson and Dembo 1984; Tschannen-Moran, Woolfolk Hoy and Hoy 1998); believe they can prevail over problems through effort and time; and are more likely to generate a lively, student-centred learning atmosphere, whereby students assume responsibility for their learning (Bandura 1997). Conversely, teachers with low levels of self-efficacy are inclined to be less prepared to work with students who are encountering learning problems; are less optimistic about student learning (Caprara, Barbaranelli, Steca and Malone 2006; Klassen et al. 2009); are overwhelmed with discipline-related matters, and turn to punitive methods of classroom management; believe that very minimal can be done to influence unenthusiastic students, and that their impact as teachers is restricted by environmental circumstances beyond their jurisdiction; and would probably dedicate more time to non-educational, managerial duties (Bandura 1997).

Numerous studies in several countries indicate that "the levels of teacher self-efficacy reported at the end of the student teaching experience are higher than when they started teaching" (Dembo and Gibson 1985; Knobloch 2006; Roberts et al. 2009; Spector 2004; Swan et al. 2011; Woolfolk and Hoy 1990; Woolfolk Hoy and Burke-Spero 2005). Studies administered to establish the self-efficacy beliefs of pre-service teachers in Turkey (Azar 2010; Demirtaş, Comert and Ozer 2011; Kutluca and Ekici 2010; Özdemir 2008; Saracaloğlu and Yenice 2009; Tarkin and Uzuntiryaki 2012), found "that pre-service teachers' self-efficacy were high". They further reported that female pre-service teachers had higher self-efficacy beliefs compared to their male counterparts (Ustuna 2017).

In spite of phenomenal studies that have been conducted on teacher self-efficacy in different countries (e.g. Anderson, Greene and Loewen 1988; Cakiroglu, Cakiroglu and Boone 2005; Gencer and Cakiroglu 2007; Goddard, Hoy and Woolfolk-Hoy 2004; Greenwood, Olejnik and Parkay 1990; Gurol et al. 2010; Isiksal and Cakiroglu 2005; Klassen and Chiu 2010; Koc 2011; Pajares 1997; Woolfolk and Hoy 1990) and South Africa (e.g. Matoti et al. 2011; 2014; Janqueira and Matoti 2013), there is a dearth of relevant information in the literature pertaining the association between personality factors and pre-service teachers' selfefficacy.

Few studies that have investigated the relationship between teaching self-efficacy and preservice teachers' personality traits, observed that there was a significant positive relationship 
between extraversion and teacher self-efficacy beliefs (Djigic, Stojiljov and Doskovic 2013; Jamil, Downer and Pianta 2012; Senler and Sungur-Vural 2013; Ustuna 2017). Conversely, neuroticism was found to be negatively associated with self-efficacy (Jamil et al. 2012; Klassen and Tze 2014; Senler and Sungur-Vural 2013; Ustuna 2017).

Consistent evidence from literature indicates "that personality characteristics predispose individuals to view events of their life in particular ways" (Kaplan 1996). In the absence of an abundance of "concrete classroom experiences on which to base future expectations, this predisposition could play a much greater role in the self-efficacy of pre-service teachers than in that of more experienced teachers" (Jamil et al. 2012). Regarding personality factors that predict pre-service teachers' self-efficacy, Jamil et al. (2012) established in their study that "pre-service teachers' levels of extraversion and neuroticism were both significant predictors of their levels of teacher self-efficacy".

\section{PROBLEM STATEMENT}

Since it has been established that teachers' sense of efficacy significantly correlated with their instructional practices and with students' achievement and motivation, there is a necessity to explore the factors that influence the development of teachers' self-efficacy beliefs, commencing with the pre-service years (Senler and Sungur-Vural 2013). "Consistent links between teacher self-efficacy and teacher persistence and resilience" (Yost 2006) presuppose that "teacher self-efficacy might play an important role in the process of teacher retention". Therefore, such a link should be promoted during teachers' pre-service years (Jamil et al. 2012). However, for this to happen, more research should be conducted to examine the factors related to the self-efficacy beliefs of pre-service teachers. Unfortunately, although studies on preservice teachers' self-efficacy have been conducted, there is paucity of studies that have attempted to investigate pre-service teachers' self-efficacy and personality factors in the ambient of South Africa. This study aims to close that gap. More precisely, this study endeavours to obtain solutions to the succeeding research questions:

1. What is the extent of pre-service teachers' teaching self-efficacy?

2. Do pre-service teachers' biographical variables, namely gender and programme of study have any influence on their teaching self-efficacy?

3. Is there any relationship between pre-service teachers' teaching self-efficacy and personality factors, namely neuroticism $(\mathrm{N})$ and extraversion $(\mathrm{E})$ ?

4. Do personality factors (neuroticism and extraversion) and biographical variables (gender and programme of study) predict pre-service teachers' teaching self-efficacy? 


\section{Aims of study}

This study sought to attain the succeeding objectives:

1. To determine the extent of pre-service teachers' teaching self-efficacy.

2. To establish whether pre-service teachers' biographical variables, namely gender and programme of study have any influence on their teaching self-efficacy.

3. To establish whether there is any relationship between pre-service teachers' teaching selfefficacy and personality factors, namely neuroticism $(\mathrm{N})$ and extraversion (E).

4. To establish whether personality factors (neuroticism and extraversion) and biographical variables (gender and programme of study) predict pre-service teachers' teaching selfefficacy.

\section{Hypotheses}

The succeeding theoretical hypotheses were postulated:

1. Pre-service teachers do not differ in terms of the extent of their teaching self-efficacy.

2. Pre-service teachers' biographical variables, namely gender and programme of study have no influence on their teaching self-efficacy.

3. There is no relationship between pre-service teachers' teaching self-efficacy and personality factors, namely neuroticism $(\mathrm{N})$ and extraversion $(\mathrm{E})$.

4. Personality factors, namely neuroticism and extraversion and biographical variables (gender and programme of study) do not predict pre-service teachers' teaching selfefficacy.

\section{CONCEPT CLARIFICATION}

Teacher "self-efficacy is defined as a teacher's judgement of his or her capabilities to bring about the desired outcomes of student engagement and learning, even amongst those students who may be difficult or unmotivated" (Tschannen-Moran et al. 1998). Teacher self-efficacy is conceptualised as a construct encompassing "three domains of self-efficacy, namely instructional strategies, classroom management, and student engagement" (Tschannen-Moran and Woolfolk Hoy 2001).

\section{THEORETICAL FRAMEWORK}

Bandura's (1993) social cognitive theory and the associated theory of self-efficacy (Bandura 
1997) contributed to teacher self-efficacy. Therefore, his theory provided the theoretical framework for this study. Bandura $(1993 ; 1994 ; 1997)$ postulates four sources of information that contribute to the formation of self-efficacy beliefs, namely mastery experiences, vicarious experiences, social persuasion, and physiological and emotional state. Mastery experiences refer to one's direct experiences. It alludes to how an individual construe the outcomes of past (Pajares 2002). The sense of self-efficacy for a person who experiences success at a task increases, whilst it decreases for the one experiencing a failure (Bandura 1994). Vicarious experiences encompass observing others performing tasks (Pajares 2002). Seeing others succeed at an assignment may increase the conviction that the one observing could also succeed in executing the assignment. The opposite may occur when observing others failing. Social persuasion occurs when others convince an individual that she or he has capabilities to succeed at a task (Swan et al. 2011). These persuasions can entail performance feedback, or exposure to verbal judgement provided by others (Pajares 2002). Physiological and emotional state refers to a person's anxiety, mood, stress and pain. In cases where individuals experience negative thoughts and fears about their capabilities, such reactions can lower their self-efficacy beliefs about their success in performing a task. However, when people reduce their stress reactions, their self-efficacy beliefs can increase (Bandura 1997; Cantrell, Young and Moore 2003; Pajares 2002; Steyn and Mynhardt 2008; Swan et al. 2011).

According to Bandura $(1993 ; 1994 ; 1997)$, "mastery experiences are the strongest source of information that contributes to self-efficacy beliefs, because they allow one to connect actual experiences to possible future outcomes. If one believes that one has completed a task successfully, self-efficacy is increased, and a precedent is established from which future expectations of success can be drawn. On the other hand, a perception of not achieving mastery on a task can lead to lowered self-efficacy and future expectations of failure" (Jamil et al. 2012).

Researchers have drawn specific sources of self-efficacy beliefs for pre-service teachers. Firstly, Woolfolk Hoy and Burke-Spero (2005) maintain "that mastery experience during student teaching and the first years of teaching, influences the development of teacher efficacy". They further maintain that teaching practice experiences in schools provide student teachers with opportunities to assess their teaching abilities. Secondly, observations of other teachers during teaching at schools could act as vicarious experience, which is another source of selfefficacy. Thirdly, Mulholland and Wallace (2001) have also established that successful verbal persuasion and mastery experience were main sources of information for developing pre-service teachers' self-efficacy. Knowledge of students' characteristics, preference for manageable activities, and previous experience with instructional activity during the pre-service years of teaching practice, helped student teachers with mastery experience. Support and 
positive feedback from their mentors in schools, served as verbal persuasion to build their sense of self-efficacy.

\section{METHOD}

\section{Participants}

The target population of the present study was fourth-year Bachelor of Education: Senior Phase and Further Education and Training (FET) students enrolled for six different specialisation programmes, namely Computer Science, Economic and Management Sciences, Languages, Natural Sciences, Mathematics, and Technology at a university of technology in South Africa. This group of students is in the final year of their studies, and has been exposed to content knowledge, teaching strategies, methods of teaching, and teaching practice experience in schools more than other Bachelor of Education students have. Prior teaching experience can be considered a "mastery experience", and, as such, serves, theoretically, as a powerful source of efficacy beliefs (e.g. Tschannen-Moran et al. 1998). It is for this reason that the final-year students were chosen for this study. The population, instead of a sample, was used because there were not many fourth-year students. Participants volunteered to participate in the study (Table 1).

Table 1: Distribution of participants in accordance with their biographical variables $(\mathrm{N}=178)$

\begin{tabular}{|c|c|c|c|c|c|c|c|}
\hline \multicolumn{2}{|c|}{ Gender } & \multicolumn{6}{c|}{ Programme of study (BEd. specialisation) } \\
\hline Male & Female & CS & EMS & Lang. & NS & Maths & Tech. \\
\hline 62 & 116 & 8 & 61 & 46 & 27 & 19 & 17 \\
\hline
\end{tabular}

CS = Computer Science; EMS = Economic and Management Sciences; Lang. = Languages; NS = Natural Sciences; Maths $=$ Mathematics; Tech. = Technology

Table 1 illustrates the apportionment of pre-service teachers according to their biographical variables (gender and programme of study). A total of 250 questionnaires were distributed and 178 were brought back. This constitutes a 71.2 per cent return rate.

\section{Measures}

The research instrument for this study comprised of three sections. The first section consisted of pre-service teachers' biographical information, namely gender and programme of study. The second section consisted of the Teachers' Sense of Efficacy Scale (TSES). The third section consisted of the Eysenck Personality Questionnaire (EPQ). 


\section{Teachers' Sense of Efficacy Scale (TSES)}

The TSES, which was originally developed by Tschannen-Moran and Woolfolk Hoy (2001), was used to assess pre-service teachers' teaching self-efficacy. The long version of the TSES consists of 24 items, comprising three subscales, namely efficacy for student engagement (eight items), efficacy for instructional strategies (eight items), and efficacy for classroom management (eight items). The TSES is a nine-point Likert scale "with anchors at 1 - Nothing, 3 - Very Little, 5 - Some Influence, 7 - Quite A Bit and, 9 - A Great Deal” (Tschannen-Moran and Woolfolk 2001). More precisely, the TSES measures teachers' beliefs about their capability to involve all students in learning, to utilise successful instructional strategies, and to manage classroom behaviours successfully (Senler and Sungur-Vural 2013). The TSES has been recommended for use in pre-service teachers, "with the authors suggesting that, for this particular population, the three-factor structure is less distinct, and the use of an overall score for teacher self-efficacy may be more appropriate than the subscale scores" (Tschannen-Moran and Woolfolk Hoy 2001). The reliability of the 24-item scale was found to be 0.94 for the full scale, 0.91 for instructional strategies, 0.90 for classroom management, and 0.87 for student engagement. (Tschannen-Moran and Woolfolk Hoy 2001). The use of the long version of the TSES has been expanded to South Africa (Matoti et. al 2011; 2013; Matoti and Junqueira 2013). Regarding this study, the internal-consistency reliability of the TSES, measured by Cronbach's alpha, was 0.88 for the full scale, and $0.67,0.75$ and 0.75 for student engagement, instructional strategies and classroom management, respectively.

As the TSES consists of 24 items, the lowest possible score is 24 (24 x 1), and the highest possible score is 216 ( $24 \times 9)$. This continuum of 24-216 was arbitrarily divided into three categories, namely: 24-88, indicating a low self-efficacy level (LSEL); 89-152, a moderate self-efficacy level (MSEL); and 153-216, a high self-efficacy level (HSEL). A respondent's summated score was classified accordingly into one of the three categories. This procedure yielded data to fulfil the first aim of the study. Data obtained through this procedure were also used together with those of pre-service teachers' biographical data in order to meet the second aim of the study.

\section{Eysenck Personality Questionnaire (EPQ)}

EPQ is a standardised instrument that measures Neuroticism (N), Extraversion (E), Psychoticism (P) and Lie (L) scales. Neuroticism and Extraversion scales were appropriate to the present study, since they may be significant in self-efficacy study due to their relationship with the affective inclinations that Bandura (2008) accentuates in his recent work. Literature also shows that these two factors contribute to a description of personality to a greater extent 
than the other two (Eysenck and Eysenck 1975; 1985). Therefore, Neuroticism subscale (consisting of 23 items) and Extraversion subscale (consisting of 21 items), which are scored "with either 1 or 0, assigned either to a yes or no answer to a given question" (Eysenck and Eysenck 1975; 1985), were selected. Previous studies that have extended EPQ to South Africa (Adendorff 1997; Ngidi 1998; 2009; 2013; Ngidi and Sibaya 2003), reported internalconsistency reliability scores which are ranging from 0.61 to 0.76 for Extraversion, and 0.75 to 0.85 for Neuroticism. In the present study, the internal-consistency reliability was 0.63 and 0.52 for Neuroticism and Extraversion respectively.

\section{Procedures}

The questionnaires were personally conducted by the researchers to the participants. A clarification of the essence of the research instrument and the motive of the study was made prior to the administration. The researchers were not lecturers of the students who participated in the study; therefore, conducting this research had no ethical implications.

For the purpose of fulfilling the objectives of the present investigation, several statistical steps were adopted. In order to determine the extent of pre-service teachers' teaching selfefficacy (first aim), the chi-square one-sample test was employed. In order to establish whether pre-service teachers' biographical variables (gender and programme of study) have any influence on their teaching self-efficacy (second aim), the chi-square test for $k$ independent samples was adopted. "The chi-square test is suitable for categorical data" (Babbie and Mouton 2001; Goddard and Melville 2001).

In order to establish whether there is any relationship between pre-service teachers' teaching self-efficacy and personality factors, namely neuroticism $(\mathrm{N})$ and extraversion $(\mathrm{E})$ (third aim), the Pearson product-moment correlation coefficient $(r)$ was employed. "The Pearson product-moment correlation coefficient $(r)$ is an appropriate parametric measure of association" (Bless and Kathura 1993).

Stepwise multiple regression analysis was adopted to establish whether personality factors (neuroticism and extraversion) and biographical variables (gender and programme of study) predict pre-service teachers' teaching self-efficacy (fourth aim). "Stepwise multiple regression analysis is typically used to determine the independent variables that are useful in predicting the dependent variable" (Borg and Gall 1989). The Statistical Package for the Social Sciences computer programme "searches for the order in which the best predictor variables (independent variables) are to be entered into the regression analysis. Hence, in regression, there are several variables on one side of the equation, and one variable (dependent variable) on the other side" (Borg and Gall 1989; Tabachnick and Fidell 1989; Babbie and Mouton 2001). 


\section{RESULTS}

Table 2 indicates that there were no observed frequencies for low self-efficacy level (LSEL). It was therefore, appropriate to collapse this LSEL category.

With respect to the first aim, the chi-square test $\left(\chi^{2}=0.215 ; \mathrm{df}=1 ; \mathrm{p}>0.05\right)$ revealed that a significant difference was observed between the moderate self-efficacy level (MSEL) and the high self-efficacy level (HSEL) categories (Table 2).

Table 2: Respondents grouped according to self-efficacy levels

\begin{tabular}{|c|c|c|}
\hline \multirow{2}{*}{} & \multicolumn{2}{|c|}{ Teaching self-efficacy levels } \\
\cline { 2 - 3 } & MSEL (89-152) & HSEL (153-216) \\
\hline Frequencies & 34 & 144 \\
\hline$\chi^{2}=67.978$ & $\mathrm{df}=1 ;$ & $\mathrm{p}<0.05$
\end{tabular}

This finding revealed that pre-service teachers differ in terms of the extent of their teaching self-efficacy. The two categories of teaching self-efficacy levels differed amongst themselves. In other words, the presence of these two MSEL and HSEL categories was not due to chance factors but was statistically significant. Consequently, the null hypothesis was rejected.

Table 3: Gender and teaching self-efficacy levels

\begin{tabular}{|c|c|c|}
\hline Gender & MSEL (89-152) & HSEL (153-216) \\
\hline Male & 13 & 49 \\
\hline Female & 21 & 95 \\
\hline$\chi^{2}=0.215 ;$ & df $=1 ;$ & $p>0.05$
\end{tabular}

The results of the analysis for the second aim indicate that no significant difference was observed between males and females with respect to reported teaching self-efficacy levels (Table 3). This finding revealed that gender had no influence on pre-service teachers' teaching self-efficacy. Whatever gender differences relating to the two teaching self-efficacy levels were due to chance factors, and not statistically significant. Consequently, the null hypothesis was not rejected.

Table 4: Programme of study and teaching self-efficacy levels

\begin{tabular}{|c|c|c|}
\hline Programme of study specialisation & MSEL (89-152) & HSEL (153-216) \\
\hline Computer Science & 3 & 38 \\
\hline EMS & 8 & 18 \\
\hline Languages & 1 & 47 \\
\hline Natural Sciences & 14 & 23 \\
\hline Mathematics & 4 & 13 \\
\hline Technology & 4 & $\mathrm{p}>0.05$ \\
\hline
\end{tabular}


Table 4 shows that no significant difference was observed amongst various specialisations of the Bachelor of Education study programme (Computer Science, Economic and Management Sciences, Languages, Natural Sciences, Mathematics, and Technology) with regard to the teaching self-efficacy levels reported. This finding showed that programme of study/specialisation had no influence on pre-service teachers' teaching self-efficacy. Whatever teaching-experience-related differences relating to the two teaching self-efficacy levels were due to chance factors, and not statistically significant. Consequently, the null hypothesis was not rejected.

Table 5: Correlation between teaching self-efficacy and Extraversion/Neuroticism

\begin{tabular}{|c|c|c|}
\hline Personality & $\mathbf{r}$ & Significant level \\
\hline Extraversion & 0.16 & 0.829 \\
\hline Neuroticism & 0.11 & 0.884 \\
\hline
\end{tabular}

The results of the analysis for the third aim show that no relationship was observed between pre-service teachers' teaching self-efficacy and personality factors, namely neuroticism and extraversion (Table 5). Therefore, the null hypothesis was not rejected.

The regression of teaching self-efficacy on predictor variables is presented in Table 6.

Table 6: Regression of teaching self-efficacy on personality factors and biographical variables

\begin{tabular}{|c|c|c|c|c|}
\hline Dependant Variable & Predictor & R2 & F & P \\
\hline Classroom Management & Programme of study & 0.03 & 4.53 & 0.04 \\
\hline
\end{tabular}

The results of the regression analysis (Table 6) reveal that only the programme of study emerged as significant predictor of efficacy for the classroom management subscale of teaching self-efficacy $(F=4.53, p<.04)$. Programme of study explained 3 per cent of the variance.

\section{DISCUSSION}

The findings disclose that pre-service teachers differed in terms of the extent of their teaching self-efficacy. A high percentage $(80.9 \%)$ of pre-service teachers reported a high level of teaching self-efficacy, in comparison to those who reported a moderate level (19.10\%) (Table 2). None of the pre-service teachers reported a low teaching self-efficacy level. This implies that the preponderance of pre-service teachers has a high level of teaching self-efficacy. These findings concur with those of other studies (Knobloch 2006; Swan et al. 2011), which reported high levels of pre-service teachers' self-efficacy. 
The findings also reveal that gender and programme of study had no influence on pre-service teachers' teaching self-efficacy (Tables 3 and 4). This implies that gender and programme of study are not significant variables that influence pre-service teachers' teaching self-efficacy. The finding that gender had no influence on pre-service teachers' teaching self-efficacy is contrast to that of Özdemir (2008), who reported that female pre-service teachers had higher self-efficacy beliefs in comparison to their male counterparts.

The findings further reveal that there is no relationship between pre-service teachers' teaching self-efficacy and personality factors, namely neuroticism $(\mathrm{N})$ and extraversion $(\mathrm{E})$ (Table 5). These findings are contrary to previous findings (Djigic, Stojiljov and Doskovic 2013; Jamil et al. 2012; Senler and Sungur-Vural 2013; Ustuna 2017), which reported a significant positive relationship between extraversion and teacher self-efficacy belief. These findings are also in contrast with the findings of other studies (Jamil et al. 2012; Klassen and Tze 2014; Senler and Sungur-Vural 2013; Ustuna 2017), which established a negative association between neuroticism and self-efficacy.

Regarding the personality factors (neuroticism and extraversion) and biographical variables (gender and programme of study) that predict pre-service teachers' teaching self-efficacy, the findings reveal that the programme of study emerged as a significant predictor of efficacy for the classroom management subscale of teaching self-efficacy (Table 6).

\section{CONCLUSION}

Drawing from the findings of the present study, the following conclusions are made: pre-service teachers' teaching self-efficacy is high; gender and programme of study have no influence on pre-service teachers' teaching self-efficacy; there is no relationship between pre-service teachers' teaching self-efficacy and personality factors, namely neuroticism $(\mathrm{N})$ and extraversion (E); and programme of study emerged as a significant predictor of efficacy for the classroom management subscale of teaching self-efficacy. Given that this study was conducted at one university of technology, further similar research at other universities is suggested.

\section{REFERENCES}

Adendorff, A. 1997. Extraversion, neuroticism and coping as variables in the burnout process: A pilot study using a population of childcare workers. Doctoral dissertation. University of Natal, Pietermaritzburg.

Anderson, R. N. F., M. L. Greene and P. S. Loewen. 1988. Relationships among teachers' and students' thinking skills, sense of efficacy, and student achievement. The Alberta Journal of Educational Research 34: 148-165.

Ashton, P. and R. Webb. 1986. Making a difference: teachers' sense of efficacy and student achievement. New York: Longman. 
Azar, A. 2010. In-service and pre-service secondary science teachers' self-efficacy beliefs about science teaching. Zonguldak Karaelmas University Journal of Social Sciences 6(12): 235-252.

Babbie, E. and J. Mouton. 2001. The practice of social research. Cape Town: Oxford University Press.

Bandura, A. 1993. Perceived self-efficacy in cognitive development and functioning. Educational Psychologist 28(2): 117-148.

Bandura, A. 1994. Self-efficacy. In Encyclopedia of human behaviour, ed. V. S. Ramachaudran Vol. 4, 71-81. New York, NY: Academic Press.

Bandura, A. 1997. Self-efficacy: The exercise of control. New York, NY: W.H. Freeman and Company.

Bandura, A. 2008. An agentic perspective on positive psychology. In Positive psychology: Exploring the best in people, ed. S. J. Lopez, Vol. 1, 167-196). Westport, CT: Greenwood.

Bless, C. and R. Kathura. 1993. Fundamental of social statistics: An African perspective. Cape Town: Juta.

Borg, W. R. and M. D. Gall. 1989. Educational research. New York: Longman.

Cantrell P., S. Young, A. Moore. 2003. Factors affecting science teaching efficacy of preservice elementary teachers. Journal of Science Teacher Education: 177-192.

Cakiroglu, J., E. Cakiroglu and W. J. Boone. 2005. Pre-service teacher self-efficacy beliefs regarding science teaching: A comparison of pre-service teachers in Turkey and the USA. Science Educator 14(1): 31-40.

Caprara, G. V., P. S. Barbaranelli, P. Steca and P. S. Malone. 2006. Teachers' self-efficacy beliefs as determinants of job satisfaction and students "academic achievement": A study at the school level. Journal of School Psychology 44: 473-490.

Coladarci, T. 1992. Teachers' sense of efficacy and commitment to teaching. Journal of Experimental Education 60: 323-337.

Cousins, J. B. and C. A. Walker. 2000. Predictors of educators' valuing of systematic inquiry in schools. Canadian Journal of Program Evaluation (Special issue): 25-53.

Dembo, M. H. and S. Gibson. 1985. Teachers' sense of efficacy: An important factor in school improvement. Elementary School Journal 86: 173-184.

Djigic, G., S., Stojiljkovic and M. Doskovic. 2013. Basic personality dimensions and teachers' selfefficacy. Procedia-Social and Behavioral Sciences 112(2014): 593-602.

Demirtaş, H., M. Cömertand, N. Özer. 2011. Pre-service teachers' self-efficacy beliefs and attitudes towards profession. Education and Science 36(159): 96-111.

Eysenck, H. J. and S. B. G. Eysenck. 1975. Manual of the Eysenck Personality Questionnaire (Junior and Adult). London: Hodder and Stroughton.

Eysenck, H. J. and S. B. G. Eysenck. 1985. Personality and individual differences. New York: Plenum Press.

Gencer, A. S. and J. Cakiroglu. 2007. Turkish pre-service science teachers' efficacy beliefs regarding science teaching and their beliefs about classroom management. Teaching and Teacher Education 23: 664-675.

Gibson, S. and M. H. Dembo. 1984. Teacher efficacy: A construct validation. Journal of Educational Psychology 76: 569-582. http://dx.doi.org/10.1037//0022-0663.76.4.569 (Accessed 10 July 2017).

Goddard, R. D., W. K. Hoy and A. W. Woolfolk-Hoy. 2004. Collective efficacy beliefs: Theoretical developments, empirical evidence, and future directions. Educational Researcher 33(3): 3-13. https://doi.org/10.3102/0013189X033003003 (Accessed 10 July 2017).

Goddard, W. and S. Melville. 2001. Research methodology: An introduction. $2^{\text {nd }}$ Edition. Landsdown: Juta.

Greenwood, G. E., S. F. Olejnik and F. W. Parkay. 1990. Relationships between four teacher efficacy belief patterns and selected teacher characteristics. Journal of Research and Development in 
Education 23(2): 102-106.

Gurol, A., M. G. Ozercan and M. Yalcin. 2010. A comparative analysis of pre-service teachers' perceptions of self-efficacy and emotional intelligence. Procedia Social and Behavioral Sciences 2: 3246-3251.

Hoy, A. W. and R. B. Spero. 2005. Changes in teacher efficacy during the early years of teaching: A comparisons of four measures. Teaching and Teacher Education 21: 343-356.

Isiksal, M. and E. Cakiroglu. 2005. Teacher efficacy and academic performance. Academic Exchange Quarterly 9: 28-33.

Jamil, F. M., J. T. Downer and R. C. Pianta. 2012. Association of pre-service teachers' performance, personality, and beliefs with teacher self-efficacy at program completion. Teacher Education Quarterly Fall: 119-138.

Junqueira, K. E. and S. N. Matoti. 2013. A comparative study of pre-service teachers' teaching efficacy beliefs before and after work-integrated learning: Part two. Africa Education Review 10(1): 2846.

Kaplan, H. B. 1996. Psychosocial stress from the perspective of self-theory. In Psychosocial stress: Perspective on structure, theory, life-course, and methods, ed. H. B. Kaplan, 175-244. San Diego, CA: Academic Press.

Klassen, R. M., M. Bong, E. L. Usher, W. H. Chong, V. S. Haun, I. Y. F. Wong and T. Georgiou. 2009. Exploring the validity of the Teachers' Self-Efficacy Scale in five countries. Contemporary Educational Psychology 34(1): 67-76.

Klassen, R. M. and M. M. Chiu. 2010. Effects on teachers' self-efficacy and job satisfaction: Teacher gender, years of experience, and job stress. Journal of Educational Psychology 102: 742-756. http://dx.doi.org/10.1037/a0019237 (Accessed 29 June 2017).

Klassen, R. M. and V. M. C. Tze. 2014. Teachers' self-efficacy, personality, and teaching effectiveness: A meta-analysis. Educational Research Review 12: 59-76. https://doi.org/10.1016/ j.edurev.2014.06.001.

Knobloch, N. A. 2006. Exploring relationships of teachers' sense of efficacy in two student teaching programs. Journal of Agricultural Education 47(2): 36-47. doi: 10.5032/jae.2006.02036. (Accessed 27 September 2017).

Koc, Y. 2011. An investigation on the effect of department and yeas spent I program on pre-service teachers' mathematics teaching efficacy beliefs. Education and Science 36: 213-223.

Kutluca, T. and G. Ekici. 2010. Examining teacher candidates' attitudes and self-efficacy perceptions towards the computer assisted education. Hacettepe University Journal of Education 38: 177-188.

Matoti, S. N., K. E. Junqueira and R. J. Odora. 2011. A comparative study of preservice teachers' selfefficacy beliefs before and after work-integrated learning. South African Journal of Higher Education 25(6): 1140-1154.

Matoti, S. N., K. E. Junqueira and R. J. Odora. 2013. Assessing the teaching efficacy beliefs of teacher trainees: A comparison of two institutions of Higher Learning in South Africa. Africa Education Review 10(4): 634-653. http://dx.doi.org/10.1080/18146627.2013.853558 (Accessed 26 June 2017).

Mulholland, J. and J. Wallace. 2001. Teacher induction. Teaching and Teacher Education 17: 243-261.

Ngidi, D. P. 1998. Towards a model for determinants of occupational stress among teachers in KwaZuluNatal. Doctoral dissertation. KwaDlangezwa: University of Zululand.

Ngidi, D. P. 2009. Black Educators' resilience in teaching as a career. Journal of Educational Studies 8(1): 22-32.

Ngidi, D. P. 2013 Students' personality traits and learning approaches. Journal of Psychology in Africa 23(1): 149-152.

Ngidi, D. P. and P. T. Sibaya. 2003. Student teacher anxieties related to practice teaching. South African Journal of Education 23(1): 12-16. 
Özdemir, S. M. 2008. An investigation of prospective primary teachers' self-efficacy beliefs regarding teaching process in terms of certain variables. Educational Administration: Theory and Practice 54: $277-306$.

Pajares, F. 1997. Current directions in self-efficacy research. In Advances in motivation and achievement, ed. M. Maehr and P. R. Pintrich, 1-49. Greenwich, CT: JAI Press.

Pajares, F. 2002. Overview of social cognitive theory and of self-efficacy. http://www.emory.edu/ EDUCATION/mfp/eff.html (Accessed 28 September 2017).

Roberts, T. G., J. F. Harlin and G. E. Briers. 2009. Predicting agricultural education student teachers' intention to enter teaching. Journal of Agricultural Education 50(3): 56-68. doi: 10.5032/jae. 2009.03056 (Accessed 11 July 2017).

Saracaloğlu, A. S. and N. Yenice. 2009. Investigating the self-efficacy beliefs of science and elementary teachers with respect to some variables. Journal of Theory and Practice in Education 5(2): 244260.

Senler B. and S. Sungur-Vural. 2013. Pre-service science teachers' teaching self-efficacy in relation to personality traits and academic self-regulation. The Spanish Journal of Psychology 16(12): 1-47.

Spector, L. D. 2004. Teachers and teaching behaviours. Psychological Reports 23: 207-214.

Steyn, R. and J. Mynhardt. 2008. Factors that influence the forming of self-evaluation and self-efficacy perceptions. South African Journal of Psychology 38: 563-573.

Swan, B. G., K. J. Wolf and J. Cano. 2011. Changes in teacher self-efficacy from the student teaching experience through the third year of teaching. Journal of Agricultural Education 52(2): 128-139. DOI: 10.5032/jae.2011.02128 (Accessed 30 June 2017).

Tabachnick, B. G. and L. S. Fidell. 1989. Using multivariate statistics. New York: Harper and Row.

Tarkın, A. and E. Uzuntiryaki. 2012. Investigation of pre-service teachers' self-efficacy beliefs and attitudes toward teaching profession through cononical analysis. Elementary Education Online 11(2): 332-341.

Tschannen-Moran, M., A. Woolfolk Hoy and W. K. Hoy 1998. Teacher efficacy: Its meaning and measure. Review of Educational Research 68(2): 202-248. http://www.jstor.org/stable/1170754 (Accessed 28 July 2017).

Tschannen-Moran, M. and A. Woolfolk Hoy. 2001. Teacher efficacy: Capturing an elusive construct. Teaching and Teacher Education 17(7): 783-805. doi: 10.1016/S0742-051X(01)00036-1 (Accessed 23 June 2017).

Ustuna, M. 2017. Personality and attitude towards teaching profession: Mediating role of self-efficacy. Journal of Education and Training Studies 5(9): 70-82. https://doi.org/ 10.11114/jets.v5i9.2536 (Accessed 26 September 2017).

Woolfolk, Hoy, A. E. 2000. Changes in teacher efficacy during the early years of teaching. Paper presented at the annual meeting of the American Educational Research Association, New Orleans.

Woolfolk, Hoy, A. E. and R. Burke-Spero. 2005. Changes in teacher efficacy during the early years of teaching: A comparison of four measures. Teaching and Teacher Education 21(4): 343-356. doi: 10.1016/j.tate.2005.01.007a (Accessed 30 June 2017).

Woolfolk, A. E. and W. K. Hoy. 1990. Prospective teachers' sense of efficacy and beliefs about control. Journal of Educational Psychology 82: 81-91.

Yost, D. S. 2006. Reflection and self-efficacy: Enhancing the retention of qualified teachers from a teacher education perspective. Teacher Education Quarterly 33(4): 59-76. 